\title{
資料
}

\section{On the Thermochemical Properties of Uranium Carbides*}

\author{
炭化ウランの熱化学的性質
}

\begin{abstract}
By Takashi MUKAIBO** and Keiji NAITO**
Although uranium carbides are becoming of considerable interest as nuclear fuel materials, few thermochemical data for these compounds are available and especially lack of specific heat data have made the assessment of these data unreliable. However, recently the authors made the measurement of specific heats on UC and $U C_{2}$ above room temperature, and the assessment of experimental data bacame possible in some accuracy.

In this paper, the specific heat functions for $U C$ and $U_{2}$ were derived as a function of temperature, from which the heats of formation, free energies of formation and entropies of formation of these carbides were also calculated as a function of temperature respectively. Then the assessment of these thermochemical data was carried out on the values so for reported.

In general, it was shown that the measurements at high temperatures by several authors gave a fairly good accordance with some scattering of data, which are not unreasonable in difficult experimental conditions. However, in order to make a more accurate estimation, especially for $\mathrm{UC}_{2}$, it is considered necessary to obtain further data precisely.
\end{abstract}

\section{INTRODUCTION}

As the uranium carbides are becoming of considerable interest as high-temperature nuclear fuel materials, a knowledge of the thermochemical properties of these carbides is of great importance. In this respect, Huber and Holley ${ }^{(1)}$ have reviewed the present state of knowledge about the heats, free energies, and entropies of the carbides of thorium, uranium and plutonium. As noticed in the paper, few measurements of thermochemical data for the U.C system have been made. However, at the Symposium on the Thermodynamics of Nuclear Materials held on 21 25 May 1962 in Vienna, several measured data on uranium carbides were appeared.

The present paper is an assessment of these $+i$ rmochemical data obtained by several authors. At first, the specific heat functions of UC and $\mathrm{UC}_{2}$ are estimated against temperature, then, the agreement of these thermochemical data is cross-checked at the same temperature.
The thermochemical properties of $\mathrm{U}_{2} \mathrm{C}_{3}$ will not be considered here, since the obtained data are not adequate to calculate them.

\section{Thermochemical Properties of Uranium Carbides}

\section{Specific heats}

As the specific heats of uranium carbides, the following estimated values have been known,

$$
\begin{gathered}
C p(\mathrm{UC})=7.6+2.85 \times 10^{-3} \mathrm{~T} \\
\quad\left(298^{\circ} \sim 2,400^{\circ} \mathrm{K}\right)^{(2)} \quad(1) \\
C p\left(\mathrm{UC}_{2}\right)=8.92+3.95 \times 10^{-9} \mathrm{~T} \\
\quad(\text { No temperature range given })^{(3)} . \quad(2)
\end{gathered}
$$

Boettcher and Schneider ${ }^{(4)}$ have reported the values of $\mathrm{UC}$ at $125^{\circ}$ and $250^{\circ} \mathrm{C}$ as 0.048

* Presented to the Panel on the Thermodynamic Properties of Uranium and Plutonium Carbides held on 8 12 Oct. 1962 in Vienna.

** 向坊 隆, 内藤奎営。Japan Atomic Energy Res. Inst. (日本原子力研究所) 
\pm 0.03 and $0.053 \pm 0.003 \mathrm{cal} / \mathrm{g}^{\circ} \mathrm{C}$ respectively, from which the following equation was taken as the specific heat function of UC in the range of $298^{\circ} \sim 2,000^{\circ} \mathrm{C}$ by Huber and Holley ${ }^{(1)}$.

$$
C p(\mathrm{UC})=8.0+0.010 T \text {. }
$$

We have measured the specific heats of $\mathrm{UC}$ and $\mathrm{UC}_{2}$ in the range of $100^{\circ} \sim 400^{\circ} \mathrm{C}^{(5)}$.

These data are shown in Fig. 1. It is seen from Fig. 1 that the estimated values by Eqs. (1) and (2) are too low, and the values by Eq. ( 3 ) are too high at high tem. peratures.

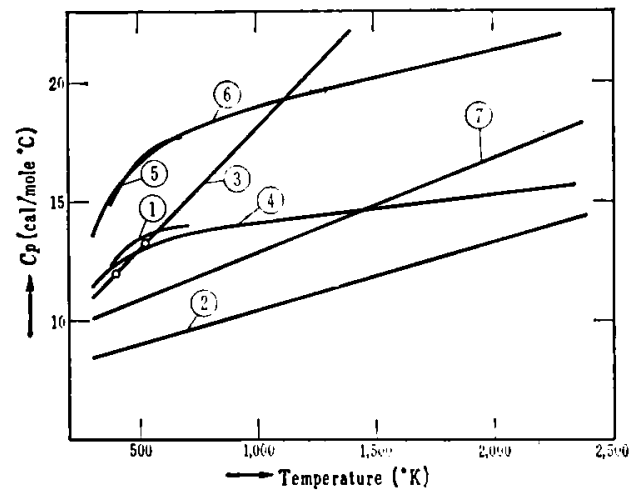

(1) $C p(\mathrm{UC})$ measured by Mukaibo, et al.

(2) $C p$ (UC)by Eq. (1)

(3) $C p$ (UC) by Eq. ( 3 )

(4) $C p$ (UC) by Eq. (4)

(5) $C p\left(\mathrm{UC}_{2}\right)$ measured by Mukaibo, et al.

(6) $C p\left(\mathrm{UC}_{2}\right)$ by Eq. (5)

(7) $C p\left(\mathrm{UC}_{2}\right)$ by Eq. ( 2$)$

Fig. 1 Specific heats of $\mathrm{UC}$ and $\mathrm{UC}_{2}$

As the data measured are not sufficient to estimate the specific heats at high temperature, the following relation was assumed for estimating them,

$$
\begin{aligned}
C p(\mathrm{UC})= & C p(\gamma-\mathrm{U} \text { or liq. } \mathrm{U})+C p(\mathrm{C}) \\
= & 13.30+1.02 \times 10^{-3} T-2.1 \\
& \times 10^{5} / T^{2}\left(298^{\circ} \sim 2,300^{\circ} \mathrm{K}\right)(4) \\
C p\left(\mathrm{UC}_{2}\right)= & C p(\gamma-\mathrm{U} \text { or liq. } \mathrm{U})+2 C p(\mathrm{C}) \\
= & 17.40+2.04 \times 10^{-3} T-4.2 \\
& \times 10^{5} / T^{2}\left(298^{\circ} \sim 2,300^{\circ} \mathrm{K}\right) .(5)
\end{aligned}
$$

The agreement of the estimated values by these equations with the measured data is satisfactory as seen in Fig. 1. It should be noticed that the assumption of Eqs. (4) and (5) is equivalent to assume $\triangle C p=0$ at tem. peratures higher than $1,045^{\circ} \mathrm{K}$ in the formation of uranium carbides.

\section{Heats of formation}

Uranium monocarbide, UC: The published measurements of heats of formation of UC are $\Delta H^{\supset_{209}}=-20 \pm 5 \mathrm{kcal} / \mathrm{mole}$ by Droege, et al..$^{(\omega)}$ and $\Delta H^{\circ}{ }_{299}=-21.0 \pm 1.0 \mathrm{kcal} / \mathrm{mole}$ by Farr, et al. ${ }^{(1)}$ Both were obtained by measuring the heat of combustion of UC, and the agreement is good. Huber and Holley ${ }^{(1)}$ took the weighed average of both data, $\Delta H^{\circ}{ }_{288}=-20.8 \pm 0.9$ $\mathrm{kcal} / \mathrm{mole}$ as the heat of formation of UC.

Alcock and Grieveson ${ }^{(8)}$ have reported the following equation for the free energy of formation of UC by the activity measurement,

$$
\begin{aligned}
& \mathrm{U}(l)+\mathrm{C}(s) \rightarrow \mathrm{UC}(s) \\
& \Delta G^{\circ}{ }=-25,200+3.6 T \\
& \left(1,723^{\circ} \sim 1,823^{\circ} \mathrm{K}\right) .
\end{aligned}
$$

The heat of formation is calculated from Eq. (7) as $\Delta H^{\circ}{ }_{1,723 \sim 1,823}=-25.2 \mathrm{kcal} / \mathrm{mole}$.

In order to check this value, we have calculated $\Delta H^{\circ}$ r using the value of $\Delta H^{\circ}{ }_{298}=$ $-20.8 \mathrm{kcal} / \mathrm{mole}$ and Eq. (4). The results are shown in Fig. 2, and the details of the calculation are shown in the Appendix. As seen from Fig. 2, the calculated value of $\Delta H^{\circ}{ }_{1,723 \sim 1,823}$ is $-25.5 \mathrm{kcal} / \mathrm{mole}$.

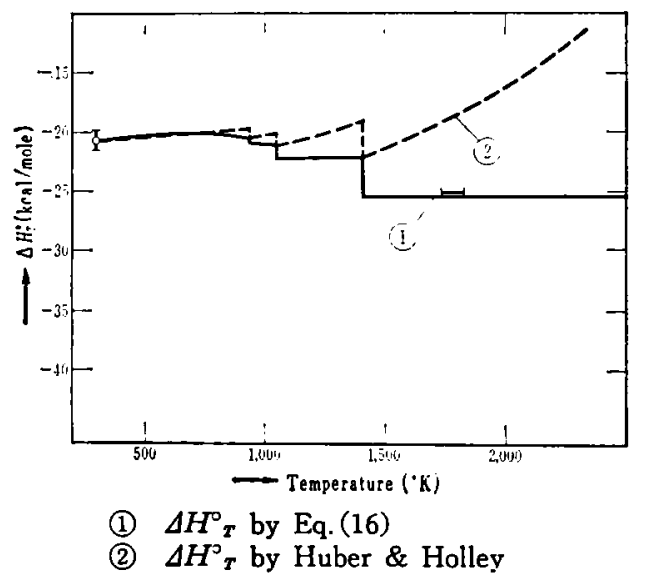

Fig. 2 Heats of formation of UC

Since the agreement of both measured values is quite satisfactory, the value of $\Delta H^{\circ}{ }^{299}$ $=-20.8 \mathrm{kcal} / \mathrm{mole}$ seems to be more reliable than other estimated values of $\Delta H^{\circ}{ }_{298}$ such as $-40 \mathrm{kcal} / \mathrm{mole}$ by Brewer, et al. ${ }^{(9)},-43 \mathrm{kcal} /$ mole by Brewer, et al. ${ }^{\infty 0}$, and $-28 \pm 6 \mathrm{kcal} /$ mole by Krikorian ${ }^{(11)}$.

The Huber and Holley's estimation for $\Delta H^{\circ}{ }^{(}{ }^{(1)}$ is also shown in Fig. 2, which has higher values at high temperatures because of the higher values of specific heat of UC 
taken.

Uranium dicarbide, $\mathrm{UC}_{2}$ : Huber and Holley ${ }^{(1)}$ have measured the heat of formation of $\mathrm{UC}_{1.86}$ as $\Delta H^{{ }^{\prime}}{ }_{298}=-18 \pm 4 \mathrm{kcal} / \mathrm{mole}$ by measuring heat of combustion. The other measured values of $\Delta H^{\circ}$ have been obtained by measuring the dissociation pressure of $\mathrm{UC}_{2}$ at high temperatures. The following equations were calculated by combining the dissociation pressures of uranium dicarbide reported by respective authors with the value for the free energy of vaporization of uranium measured by Alcock and Grieveson ${ }^{(12)}$.

$$
\begin{array}{r}
\mathrm{U}(l)+2 \mathrm{C}(s) \rightarrow \mathrm{UC}_{2}(s) \quad(8) \\
\Delta G^{\circ}{ }_{T}=-30,000+1.53 T\left(2,450^{\circ} \sim 2,730^{\circ} \mathrm{K}\right) \\
\quad \text { by Fujishiro }{ }^{(13)},(9) \\
\Delta G^{\circ}{ }_{T}=-22,300-5.73 T\left(1,930^{\circ} \sim 2,365^{\circ} \mathrm{K}\right) \\
\text { by Leitnaker \& Witteman }{ }^{(14)},(10) \\
\Delta G^{\circ}{ }_{T}=-19,900-5.80 T\left(2,000^{\circ} \sim 2,900^{\circ} \mathrm{K}\right) \\
\text { by Lonsdale \& Graves (15), (11) } \\
\Delta G^{\circ}{ }_{T}=-32,600+3.6 T\left(1,973^{\circ} \sim 2,073^{\circ} \mathrm{K}\right) \\
\text { by Alcock \& Grieveson }{ }^{(8)},(12) \\
\Delta G^{\circ}{ }=-48,100+4.49 T\left(2,060^{\circ} \sim 2,460^{\circ} \mathrm{K}\right) \\
\text { by Eick, et al. }{ }^{(16)}(13)
\end{array}
$$

Fig. 3 shows the values of $\Delta H^{\circ}$ r obtained from these Eqs. (9) (13) and Eq. (5). In this figure, $\Delta H^{\circ}{ }_{T}$ calculated from Huber and Holley's value of $\Delta H^{\circ}{ }_{298}=-18 \mathrm{kcal} / \mathrm{mole}$ is also shown. As a whole, the agreement of these values is not good with the exception

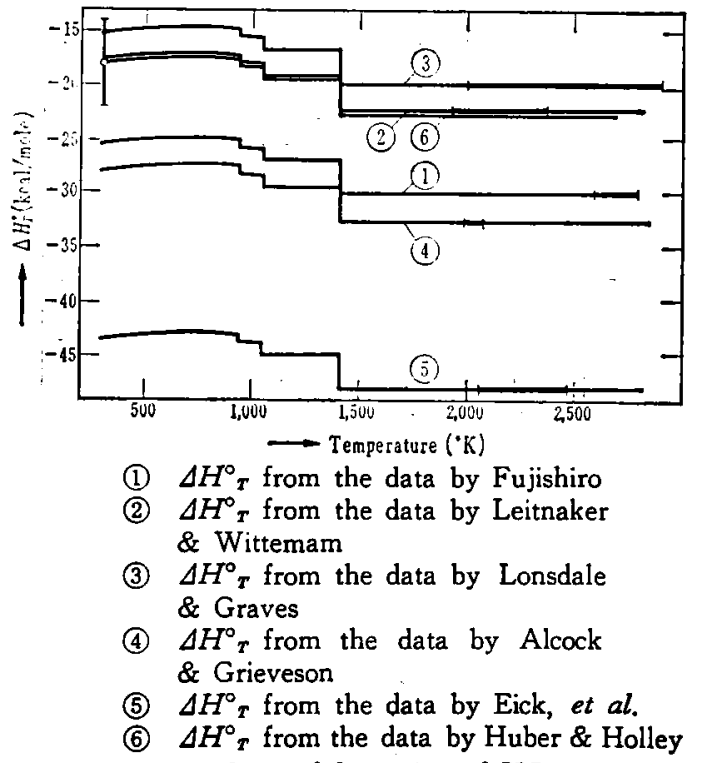

Fig. 3 Heats of formation of $\mathrm{UC}_{2}$ that $\Delta H^{\circ}{ }_{\boldsymbol{r}}$ by Leitnaker and Witteman is in good accordance with that by Huber and Holley.

The estimated values of $\Delta H^{\circ}{ }_{298}$ are also known as $-36 \mathrm{kcal} / \mathrm{mole}$ by Brewer, et al. ${ }^{\text {(9)a }}$, $-42 \mathrm{kcal} / \mathrm{mole}$ by Rossini, et al. ${ }^{(17)}$, and -27 $\pm 8 \mathrm{kcal} / \mathrm{mole}$ by Krikorian ${ }^{(11)}$.

The disagreement of these values leads to the conclusion that more careful measurement will be needed.

\section{Free energies of formation}

Uranium monocarbide, UC: The data by Alcock and Grieveson ${ }^{(8)}$ shown in Eq. (7) represents the only measurement of the free energy of formation of uranium monocarbide. Then, as shown in the Appendix, we calculat'ed $\Delta G^{\circ}{ }_{T}$ by using the value of $\Delta G^{\circ}{ }_{1,800}$ from Eq. ( 7 ) and $\Delta H_{T}$ functions obtained already.

The results are shown in Fig. 4. $\Delta G^{\circ}{ }_{288}$ is obtained as $-20.5 \mathrm{kcal} / \mathrm{mole}$.

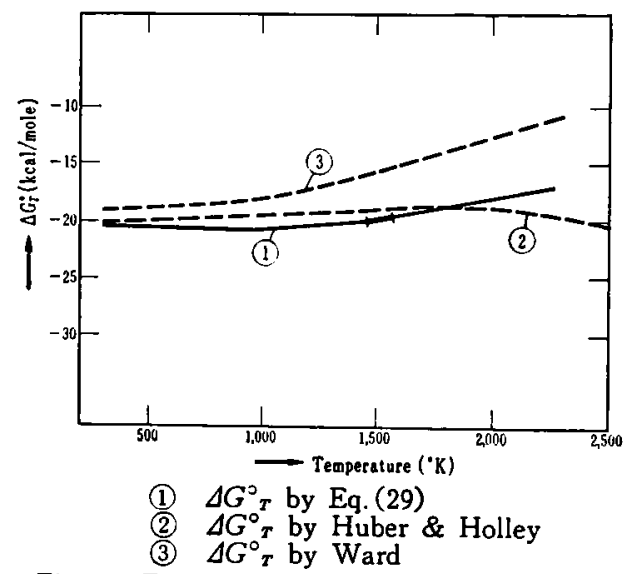

Fig. 4 Free energies of formation of UC

In this figure, the estimated equations for $\Delta G^{\circ}$ by Huber and Holley ${ }^{(1)}$ and by Ward ${ }^{(2)}$ are also shown.

As the estimated value of $\Delta G^{\circ}{ }_{298}$ of $\mathrm{UC}$, Brewer, et al. ${ }^{(9)}$ have reported $-41 \mathrm{kcal} / \mathrm{mole}$. It is necessary to have more experimental data in order to make the evaluation of values mentioned above.

Uranium dicarbide, $\mathrm{UC}_{2}$ : The measured values of $\Delta G^{\circ}$ of $\mathrm{UC}_{2}$ are shown in Eqs. (9) $\sim$ (13) which were all obtained by measuring the dissociation pressure of $\mathrm{UC}_{2}$ at high temperatures.

$\Delta G^{\circ}{ }_{r}$ were calculated from Eqs. (9) (13) and Eq. (5) as shown in the Appendix, 
and the results are given in Fig. 5. In this figure, the curve (6) was obtained by using the value of $\Delta G^{\circ}{ }_{2,023}$ from Alcock and Grieveson's measurement and $\Delta H^{\prime}{ }_{T}$ function from Huber and Holley's measurement.

As seen from Fig. 5, the values of $\Delta G^{\circ}{ }_{283}$ are in the range of $-18 \sim-43 \mathrm{kcal} / \mathrm{mole}$.

The estimated equations for $\Delta G^{2}$ by Huber and Holley ${ }^{(1)}$ and by Ward ${ }^{(2)}$ are shown in Fig. 5.

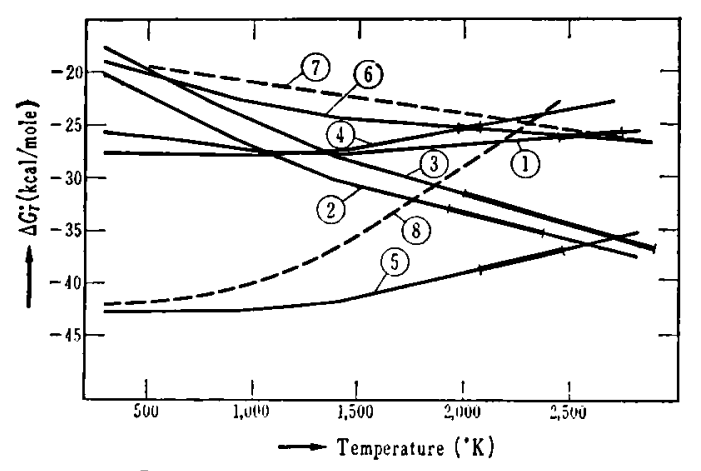

(1) $\Delta G^{\circ}$ from the data by Fujishiro

(2) $\Delta G^{\circ}{ }_{r}$ from the data by Leitnaker \& Witterman

(3) $\Delta G^{\circ}{ }_{r}$ from the data by Lonsdale \& Graves

(4) $\Delta G^{\circ}$ from the data by Alcock \& Grieveson

(5) $\Delta G^{\circ}{ }_{r}$ from the data by Eick, et al.

(6) $\Delta G^{2} r$ from the data by Huber

\& Holley, and Alcock \& Grieveson

(7) $\Delta G^{\circ}$ by Huber \& Holley

(8) $\Delta G^{2}{ }_{r}$ by Ward

Fig. 5 Free energies of formation of $\mathrm{UC}_{2}$

The estimated values of $\Delta G^{3}{ }^{298}$ of $\mathrm{UC}_{2}$ are known as $-38 \mathrm{kcal} / \mathrm{mole}$ by Brewer, et al. ${ }^{(9)}$, $-42 \mathrm{kcal} / \mathrm{mole}$ by Rossini, et al. ${ }^{(17)}$

To evaluate these values, it is necessary to determine $\Delta G^{\circ}$ at lower temperatures.

\section{Entropies of formation}

Uranium monocarbide, UC: There are no measurements of low temperature heat capacities from which the entropy of UC could be determined.

The estimated values of $\Delta S^{\circ}{ }_{288}$ of UC are known as +2 e.u. by Brewer, et al. $.^{(9)},-2$ e.u. by Brewer, et al. ${ }^{00},-3.4$ e.u. by $\operatorname{Ward}^{(2)}$, $-1.5 \pm 1.5$ e.u. by Krikorian ${ }^{(11)}$, and -2.1 e.u. by Huber and Holley ${ }^{(1)}$, which are scattered around 0 e.u.

We have made the calculation of $\Delta S^{\circ}$ by using $\Delta H^{\circ}$ and $\Delta G^{\circ}{ }_{T}$ functions determined above. The results are shown in Fig. 6. The value of $\Delta S^{3}{ }_{298}$ is . derived to be -0.9 e.u., which gives the entropy of UC as $S^{3}{ }_{300}$ $=12.5$ e.u.

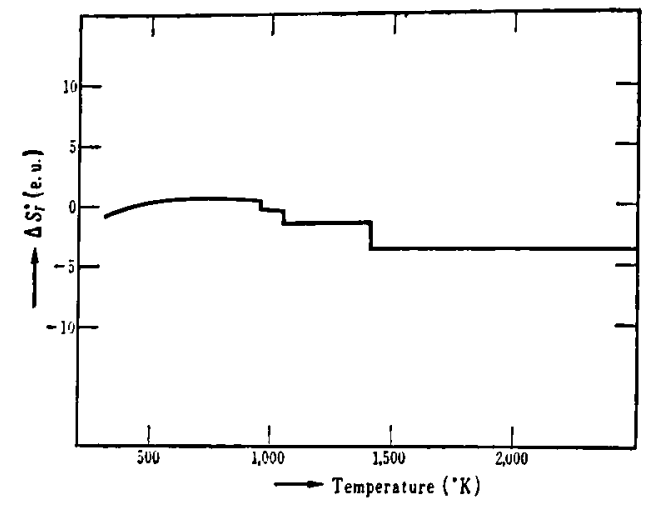

Fig. 6 Entropy of formation of UC

Uranium dicarbide, $\mathrm{UC}_{2}$ : No experimental data of low temperature heat capacities of $\mathrm{UC}_{2}$ are available.

The estimated values of $\Delta S^{\circ}{ }_{298}$ of $\mathrm{UC}_{2}$ are known as +4 e.u. by Brewer, et al. ${ }^{(9)},-0.8$ e.u. (or $S^{\circ}{ }_{288}\left(\mathrm{UC}_{2}\right)=14$ e.u.) by Rossini, et al. ${ }^{(17)},-5$ e.u. by Brewer, et al. ${ }^{00},+2.8 \pm$ 3.0 e.u. by Krikorian ${ }^{(11)}$, and +4.1 e.u. (or $S_{288}^{\circ}\left(\mathrm{UC}_{2}\right)=18.88$ e.u. $)$ by Leitnaker and Witteman ${ }^{(13)}$.

Fig. 7 shows the results of our calculation of $\Delta S^{\circ}{ }_{T}$. The values of $\Delta S^{\circ}{ }_{298}$ are in the

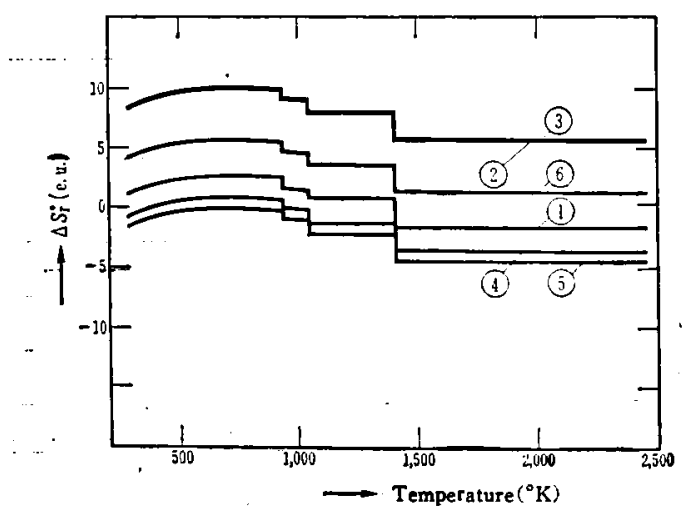

(1) $\Delta S^{2}{ }_{T}$ from the data by Fujishiro

(2) $\Delta S_{T}^{\circ}$ from the data by Leitnaker $\&$ Witteman

(3) $\Delta S^{\curvearrowright}{ }_{T}$ from the data by Lonsdale $\&$ Graves

(4) $\Delta S^{\circ}$ from the data by Alcock \& Grieveson

(5) $\Delta S^{\circ}{ }_{T}$ from the data by Eick, et al.

(6) $\Delta S^{\circ}{ }_{T}$ from the data by Huber \& Holley, and Alcock \& Grieveson

Fig. 7 Entropies of formation of $\mathrm{UC}_{2}$ 
range of $-1.3 \sim+8.7$ e.u., which give the value of the entropy of $\mathrm{UC}_{2}$ in the range of i3.5 23.5 e.u.

\section{Conclusion}

The assessment of such thermochemical data of $\mathrm{UC}$ and $\mathrm{UC}_{2}$ as heat capacity, heat of formation and free energy of formation was carried out on the values so far reported.

In general, it was recognized that the measurements at high temperatures by several authors gave a fairly good accordance with some scattering of data, which are not unreasonable in difficult experimental conditions.

However, in order to make a more accurate estimation, especially for $\mathrm{UC}_{2}$, it is considered to be necessary to obtain further data on such items as the heat of combustion at lower temperatures with samples of the accurately known assay, or a measurement of free energy of formation by some direct method, such as e.m.f. measurements using $\mathrm{UC}$ or $\mathrm{UC}_{2}$ as an electrode.

The authors wish to thank Messrs. Toshio Uchijima, Kunihiro Goto, Takeo Fujino and Kinji Ouchi for their assistance in the calculation. They are also indebted to Drs. Keichi Oshima, Toshio Nakai and Kenjiro Kimura for their continuing encouragement.

(Received February 16, 1963)

\section{[Appendix]}

\section{Specific heats}

The specific heats of UC and $\mathrm{UC}_{2}$ were obtained assuming that

$$
\begin{aligned}
& C p(\mathrm{UC})=C p(\gamma-\mathrm{U} \text { or liq. } \mathrm{U})+C p(\mathrm{C}) \\
& C p\left(\mathrm{UC}_{2}\right)=C p(\gamma-\mathrm{U} \text { or liq. } \mathrm{U})+2 C p(\mathrm{C})
\end{aligned}
$$

Taking $^{(18)}$

$$
\begin{aligned}
C p(\gamma-\mathrm{U})=C p(\text { liq. } \mathrm{U})=9.2 & \left(\text { above } 1,045^{\circ} \mathrm{K}\right) \\
C p(\text { graphite })= & 4.10+1.02 \times 10^{-\mathrm{s}} T-2.1 \\
& \times 10^{5} / T^{2} \quad\left(298^{\circ} \sim 2,300^{\circ} \mathrm{K}\right)
\end{aligned}
$$

we have

$$
\begin{aligned}
C p(\mathrm{UC})= & 13.30+1.02 \times 10^{-3} T-2.1 \\
& \times 10^{5} / T^{2}\left(298^{\circ} \sim 2,300^{\circ} \mathrm{K}\right)(4) \\
-C p\left(\mathrm{UC}_{2}\right)= & 17.40+2.04 \times 10^{-3} T-4.2 \\
& \times 10^{5} / T^{2}\left(298^{\circ} \sim 2,300^{\circ} \mathrm{K}\right) .(5)
\end{aligned}
$$

\section{Heats of formation}

Uranium monocarbide: We calculate the heat of formation for $U(\alpha-, \beta-, \gamma-$, liq. $)$ $+\mathrm{C}(s) \rightarrow \mathrm{UC}(s)$.

Taking $^{(18)(19)}$

$$
\left.\begin{array}{cc}
C p(\alpha-\mathrm{U})=3.3+8.02 \times 10^{-3} \mathrm{~T} \\
+0.7 \times 10^{5} / T^{2}\left(298^{\circ} \sim 935^{\circ} \mathrm{K}\right) \\
C p(\beta-\mathrm{U})=10.2 & \left(935^{\circ} \sim 1,045^{\circ} \mathrm{K}\right) \\
C p(\gamma-\mathrm{U})=9.2 & \left(1,045^{\circ} \sim 1,405^{\circ} \mathrm{K}\right) \\
C p(\text { liq.U })=9.2 & \left(1,405^{\circ} \sim 3,000^{\circ} \mathrm{K}\right) \\
\alpha-\mathrm{U} \rightarrow \beta-\mathrm{U}: & \Delta H=674 \mathrm{cal}\left(935^{\circ} \mathrm{K}\right) \\
\beta-\mathrm{U} \rightarrow \gamma-\mathrm{U}: & \Delta H=1,085 \mathrm{cal} \\
& \left(1,045^{\circ} \mathrm{K}\right) \\
\gamma-\mathrm{U} \rightarrow \text { liq. } \mathrm{U}: & \Delta H=3,200 \mathrm{cal} \\
& \left(1,405^{\circ} \mathrm{K}\right) \\
C p \text { (graphite })=4.10+1.02 \times 10^{-3} \mathrm{~T} \\
-2.1 \times 10^{5} / T^{2} \\
\\
& \left(298^{\circ} \sim 2,300^{\circ} \mathrm{K}\right) .
\end{array}\right)
$$

we have

$$
\begin{aligned}
& \begin{aligned}
\Delta C P= & 5.9-8.02 \times 10^{-3} T-0.7 \\
& \times 10^{5} / T^{2} \quad\left(298^{\circ} \sim 935^{\circ} \mathrm{K}\right)
\end{aligned} \\
& \triangle C p=-1.0 \quad\left(935^{\circ} \sim 1,045^{\circ} \mathrm{K}\right) \\
& \triangle C P=0 \quad \text { (above } 1,045^{\circ} \mathrm{K} \text { ). }
\end{aligned}
$$

We then get the following equations

$$
\left.\begin{array}{rl}
\Delta H^{\circ}= & \Delta H^{\circ}{ }_{288}+\int_{288}^{T} C p d T \\
= & -20,800+\int_{288}^{r} C p d T \\
\Delta H_{T}{ }^{\circ}= & -22,440+5.9 T-4.01 \\
& \times 10^{-3} T^{2}+0.7 \times 10^{5} / T \\
\left(298^{\circ} \sim 935^{\circ} \mathrm{K}\right) \\
\Delta H^{\circ}= & -20,120-1.0 T \\
\left(935^{\circ} \sim 1,045^{\circ} \mathrm{K}\right) \\
\Delta H^{\circ}{ }_{r}=22,250 \quad\left(1,045^{\circ} \sim 1,405^{\circ} \mathrm{K}\right) \\
\left.\Delta H^{\circ}{ }_{T}=-25,450 \quad \text { (above } 1,405^{\circ} \mathrm{K}\right) .
\end{array}\right\}
$$

Uranium dicarbide: Using the values of respective specific heats shown above, $\Delta C p$ for $\mathrm{U}\left(\alpha^{-}, \beta^{-}, \gamma^{-}\right.$, liq. $)+2 \mathrm{C}(s) \rightarrow \mathrm{UC}_{2}(s)$ are calculated as follows

$$
\left.\begin{array}{rr}
\Delta C p=5.9-8.02 \times 1.0^{-3} T-0.7 \\
\times 10^{3} / T^{2} & \left(298^{\circ} \sim 935^{\circ} \mathrm{K}\right) \\
\Delta C p=-1.0 & \left(935^{\circ} \sim 1,045^{\circ} \mathrm{K}\right) \\
\Delta C p=0 & \text { (above } \left.1,045^{\circ} \mathrm{K}\right) .
\end{array}\right\}
$$

Then, the heat of formation is obtained by taking Huber and Holley's value ${ }^{(1)}, \Delta H^{\circ}{ }^{298}=$ $-18,000 \mathrm{cal} / \mathrm{mole}$, 


$$
\left.\begin{array}{c}
\Delta H^{{ }}{ }_{T}=-19,640+5.9 T-4.01 \\
\times 10^{-3} T^{2}+0.7 \times 10^{5} / T \\
\left(298^{\circ} \sim 935^{\circ} \mathrm{K}\right) \\
\Delta H^{\circ}=-17,320-1.0 T \\
\left(935^{\circ} \sim 1,045^{\circ} \mathrm{K}\right) \\
\Delta H^{{ }^{\circ}}=-19,450\left(1,045^{\circ} \sim 1,405^{\circ} \mathrm{K}\right) \\
\Delta H^{{ }}{ }_{T}=-22,650 \quad\left(\text { above } 1,405^{\circ} \mathrm{K}\right) .
\end{array}\right\}
$$

On the other hand, the following measured data of dissociation pressure of $\mathrm{UC}_{2}$ at high temperatures are reported

$$
\begin{aligned}
& \mathrm{UC}_{2}(s) \rightarrow \mathrm{U}(\mathrm{g})+2 \mathrm{C}(s) \\
& \log P=\alpha / T+\beta
\end{aligned}
$$

where,

$$
\begin{aligned}
& \begin{array}{lll}
\alpha & \beta & \begin{array}{l}
\text { Temperature } \\
\text { range }\left({ }^{\circ} \mathrm{K}\right)
\end{array} \quad \text { Reference }
\end{array} \\
& -30,6006.36 \quad 2,450 \sim 2,730 \quad \text { Fujishiro }{ }^{(12)} \\
& \begin{array}{llll}
-28,930 & 4.77 \quad 1,930 \sim 2,365 \quad \text { Leitnaker \& }
\end{array} \\
& \text { Witteman }{ }^{(13)} \\
& -28,400 \quad 4.76 \quad 2,000 \sim 2,900 \text { Lonsdale \& } \\
& \text { Graves }^{(14)} \\
& -31,1706.81 \quad 1,973 \sim 2,073 \quad \text { Alcock \& Grieveson }{ }^{(8)} \\
& \text {-34,586 } 7.01 \quad 2,060 \sim 2,460 \text { Eick, et al. }{ }^{(15)}
\end{aligned}
$$

The pressure equations are converted to the free energy of formation equations using the relation

$$
\left.\begin{array}{c}
\Delta G^{\circ}=-R T \ln P \\
\Delta G^{\circ}=+140,000-29.10 T \\
\text { by Fujishiro } \\
\Delta G^{\circ}{ }_{r}=+132,320-21.82 T \\
\text { by Leitnaker \& Witteman } \\
\Delta G^{\circ}=+129,900-21.77 T \\
\text { by Lonsdale \& Graves } \\
\Delta G^{\circ}{ }_{r}=+142,600-31.17 T \\
\text { by Alcock \& Grieveson } \\
\Delta G^{\circ}=+158,100-32.06 T \\
\text { by Eick, et al. }
\end{array}\right\}
$$

Combining the equations with the values for the free energy of vaporization of uranium measured by Alcook and Grieveson ${ }^{(16)}$, the following free energy of formation equations of $\mathrm{UC}_{2}$ from liquid uranium and solid carbon are obtained

$$
\begin{aligned}
& \mathrm{U}(l)+2 \mathrm{C}(s) \rightarrow \mathrm{UC}_{2}(s) \\
& \Delta G^{\circ}{ }_{T}=-30,000+1.53 T \\
& \Delta G^{\circ}{ }_{T}=-22,320-5.73 T \\
& \quad \text { by Leitnaker \& Witteman (10) } \\
& \Delta G^{\circ}{ }_{T}=-19,900-5.80 T \\
& \quad \text { by Lonsdale \& Graves (11) } \\
& \Delta G^{\circ}{ }_{T}=-32,600+3.6 T \\
& \text { by Alcock \& Grieveson (12) }
\end{aligned}
$$

$$
\Delta G^{\circ}{ }_{T}=-48,100+4.49 T
$$

by Eick, et al. (13)

$\Delta H^{\circ}$ at each temperature region are obtained according to the relation

$$
\begin{aligned}
& \Delta H=-[\partial(\Delta G / T) / \partial T] T^{2} \\
& \Delta H^{\circ}\left(2,450^{\circ} \sim 2,730^{\circ} \mathrm{K}\right)=-30,000 \\
& \text { by Fujishiro } \\
& \Delta H^{\circ}\left(1,930^{\circ} \sim 2,365^{\circ} \mathrm{K}\right)=-22,320 \\
& \text { by Leitnaker \& Witteman } \\
& \Delta H^{\circ}\left(2,000^{\circ} \sim 2,900^{\circ} \mathrm{K}\right)=-19,900 \\
& \text { by Lonsdale \& Graves } \\
& \Delta H^{\circ}\left(1,973^{\circ} \sim 2,073^{\circ} \mathrm{K}\right)=-32,600 \\
& \text { by Alcock \& Grieveson } \\
& \Delta H^{\circ}\left(2,060^{\circ} \sim 2,460^{\circ} \mathrm{K}\right)=-48,100 \\
& \text { by Eick, et al. }
\end{aligned}
$$

Then, the heat of formation equations of $\mathrm{UC}_{2}$ are derived according to the relation

$$
\Delta H^{\circ}{ }_{r}=\int \Delta C p d T+I
$$

where, the constant, $I$, above $1,405^{\circ} \mathrm{K}$ is evaluated from the value of $\Delta H^{\circ}$ obtained above.

Then

$$
\left.\begin{array}{rr}
\Delta H^{\circ}{ }_{T}=a_{1}+5.9 T-4.01 \times 10^{-3} T^{2} \\
+0.7 \times 10^{5} / T\left(298^{\circ} \sim 935^{\circ} \mathrm{K}\right) \\
\Delta H^{\circ}{ }_{T}=a_{2}-1.0 T \quad\left(935^{\circ} \sim 1,045^{\circ} \mathrm{K}\right) \\
\Delta H^{\circ}{ }_{T}=a_{3} \quad\left(1,045^{\circ} \sim 1,405^{\circ} \mathrm{K}\right) \\
\Delta H^{\circ}=a_{4} \quad\left(\text { above } 1,405^{\circ} \mathrm{K}\right)
\end{array}\right\}
$$

here,

$$
\begin{array}{cccc}
a_{1} & a_{2} & a_{3} & a_{4} \\
-26,990 & -24,670 & -26,800 & -30,000 \\
& \text { by Fujishiro } \\
-19,340 & -16,990 & -19,120-22,320 \\
& \text { by Leitnaker \& Witteman } \\
-16,890 & -14,570-16,700-19,900 \\
& \text { by Lonsdale \& Graves } \\
-29,590 & -27,200-29,400-32,600 \\
\text { by Alcock \& Grieveson } \\
-45,090 & -42,770-44,900-48,100 \\
& \text { by Eick, et al. }
\end{array}
$$

The values of $\Delta H^{{ }^{2}}$ es thus calculated are shown below.

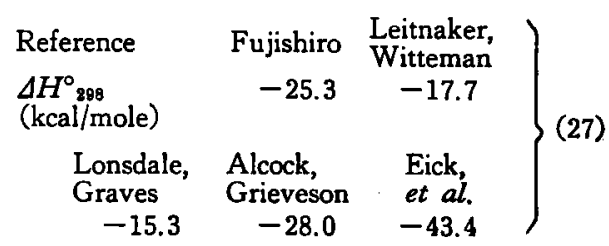

\section{Free energies of formation}

Uranium monocarbide: The free energies of formation for $U\left(\alpha^{-}, \beta^{-}, \gamma^{-}\right.$, liq. $)+C(s)$. 
$\rightarrow \mathrm{UC}(s)$ are derived according to the relation

$$
\Delta G^{\circ} / T=-\int\left(\Delta H^{\circ} / T_{s}\right) d T+I
$$

where, $H^{\circ}$ r have been obtained as shown in Eq. (16), and the constant, $I$, above $1,405^{\circ} \mathrm{K}$ is evaluated from the following experimental value by Alcock and Grieveson ${ }^{(8)}$

$$
\begin{aligned}
& \mathrm{U}(l)+\mathrm{C}(s) \rightarrow \mathrm{UC}(s) \\
& \Delta G^{\circ}{ }_{T}=-25,200+3.6 T \\
& \quad\left(1,723^{\circ} \sim 1,823^{\circ} \mathrm{K}\right)
\end{aligned}
$$

Using the value, $\Delta G^{\circ}{ }_{1,800}=-18,720 \mathrm{cal} / \mathrm{mole}$, we get the following free energy equations

$$
\left.\begin{array}{r}
\Delta G^{{ }}{ }_{T}=-22,440+38.37 T-13.59 T \log T \\
+0.35 \times 10^{5} / T+4.01 \times 10^{-3} T^{2} \\
\left(298^{\circ} \sim 935^{\circ} \mathrm{K}\right) \\
\Delta G^{{ }^{\circ}}=-20,120-7.530 T+2.303 T \log T \\
\quad\left(935^{\circ} \sim 1,045^{\circ} \mathrm{K}\right) \\
\Delta G^{{ }{ }_{T}=}=-22,250+1.461 T \\
\left(1,045^{\circ} \sim 1,405^{\circ} \mathrm{K}\right) \\
\Delta G^{\circ}{ }_{T}=-25,450+3.739 T \\
\text { (above } \left.1,405^{\circ} \mathrm{K}\right) .
\end{array}\right\}
$$

From these equations we find

$$
\Delta G^{\circ}{ }_{288}=-20.5 \mathrm{kcal} / \mathrm{mole} \text {. }
$$

Uranium dicarbide: The experimental data of $\Delta G^{j}$ for the reaction, $\mathrm{U}(l)+2 \mathrm{C}(s) \rightarrow \mathrm{UC}_{2}$ $(s)$, are shown in Eqs. $(9) \sim(13)$. Then, $\Delta G^{\circ}{ }_{r}$ at each temperature range are derived by using Eqs. (28) and (26) as following

$$
\begin{aligned}
& \Delta G^{2}{ }_{T}=a_{1}+b_{1} T-13.59 T \log T+0.35 \\
& \times 10^{5} / T+4.01 \times 10^{-3} T^{2} \\
& \left(298^{\circ} \sim 935^{\circ} \mathrm{K}\right)
\end{aligned}
$$

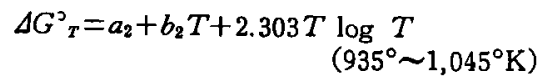

$$
\begin{aligned}
& \Delta G^{\circ}{ }=a_{3}+b_{8} T \quad\left(1,045^{\circ} \sim 1,405^{\circ} \mathrm{K}\right) \\
& \Delta G^{c}{ }_{T}=a_{4}+b_{4} T \quad \text { (above } 1,405^{\circ} \mathrm{K} \text { ) }
\end{aligned}
$$

where, the values of $a_{1}-a_{4}$ are shown in Eq. $(26)^{\prime}$, and $b_{1}-b_{4}$ are

$$
\begin{aligned}
& \begin{array}{ccccc}
b_{1} & b_{2} & b_{3} & b_{4}
\end{array} \\
& +36.2-9.72-0.744+1.533 \\
& \text { by Fujishiro } \\
& \begin{array}{llll}
+28.94 & -17.00 & -8.011 & -5.733
\end{array} \\
& \text { by Leitnaker \& Witteman } \\
& \begin{array}{r}
+28.84-17.06-8.078-5.80 \\
\text { by Lonsdale \& Graves }
\end{array} \\
& +38.21-7.690+1.332+3.6 \\
& \text { by Alcock \& Grieveson } \\
& +392-6.76+2.21+4.49 \\
& \text { by Eick, et al. }
\end{aligned}
$$

We then get the values of $\Delta G^{\supset}{ }_{298}$ as follows.

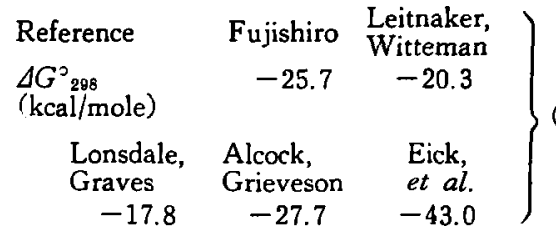

As $\Delta H^{\nu}{ }^{2}$, we derived another equation from the value obtained by Huber and Holley $^{(1)}$ as shown in Eq. (18). From this equation, we can aiso calculate $\Delta G^{\circ}{ }_{T}$ according to Eq. (28).

However, the constant, I, should be evaluated from the value of $\Delta G^{\circ}$ at given temparature. If we take $\Delta G^{\circ}{ }_{2,023}=-25,320$ $\mathrm{cal} / \mathrm{mole}$, from the measurement by Alcock and Grieveson $^{(12)}$ shown in Eq. (12), for example, we get the following equation of $\Delta G^{\circ}{ }_{T}$

$$
\left.\begin{array}{r}
\Delta G^{\circ}{ }_{T}=-19,640+33.25 T-13.59 T \log T \\
+4.01 \times 10^{-3} T^{2}+0.35 \times 10^{5} / T \\
\left(298^{\circ} \sim 935^{\circ} \mathrm{K}\right) \\
\Delta G^{\circ}{ }_{T}=-17,320-11,940 T+2.303 T \log T \\
\left(935^{\circ} \sim 1,045^{\circ} \mathrm{K}\right) \\
\Delta G^{\circ}{ }_{T}=-19,450-3.646 T \quad \\
\left(1,045^{\circ} \sim 1,405^{\circ} \mathrm{K}\right) \\
\Delta G^{\circ}{ }_{T}=-22,650-1.362 T \\
\text { (above } \left.1,405^{\circ} \mathrm{K}\right) .
\end{array}\right\}
$$

Similar calculation can be made with any value from Eqs. (9) (13).

\section{Entropies of formation}

Uranium monocarbide: The entropies of formation for $\mathrm{U}\left(\boldsymbol{\alpha}^{-}, \boldsymbol{\beta}^{-}, \boldsymbol{\gamma}^{-}\right.$, liq. $)+\mathrm{C}(s) \rightarrow$ $\mathrm{UC}(s)$ are derived according to the relation

$$
\Delta S=(\Delta H-\Delta G) / T
$$

From Eqs. (16), (29) and (34), we get

$$
\begin{array}{rr}
\Delta S^{\circ}{ }_{T}= & -32.470+13.59 \log T-8.02 \\
& \times 10^{-3} T+0.35 \times 10^{5} / T^{2} \\
\Delta S^{\circ}= & \left(298^{\circ} \sim 935^{\circ} \mathrm{K}\right) \\
& 6.530-2.303 \log T \\
\Delta{S^{\circ}}^{\circ}=-1.46 \quad\left(935^{\circ} \sim 1,045^{\circ} \mathrm{K}\right) \\
\Delta{S^{\circ}}^{\circ}=-3.74 \quad\left(1,045^{\circ} \sim 1,405^{\circ} \mathrm{K}\right) \\
\end{array}
$$

Then

$$
\Delta S^{\circ}{ }_{298}=-0.9 \text { e.u. }
$$

Uranium dicarbide: From Eqs. (26),(31) and (34), we have the following equations 


$$
\left.\begin{array}{rr}
\Delta S^{\circ}{ }_{T}=-\left(b_{1}-5.9\right)+13.59 \log T-8.02 \\
& \times 10^{-3} T+0.35 \times 10^{3} / T^{2} \\
\Delta S^{\circ}{ }_{T}=-\left(b_{2}+1.0\right)-2.303 \log T & \left(298^{\circ} \sim 935^{\circ} \mathrm{K}\right) \\
\Delta S^{\circ}{ }_{T}=-b_{3} & \left(935^{\circ} \sim 1,045^{\circ} \mathrm{K}\right) \\
\Delta S^{\circ}{ }_{T}=-b_{4} & \left(1,045^{\circ} \sim 1,405^{\circ} \mathrm{K}\right) \\
{ }_{1} & \text { (above } \left.1,405^{\circ} \mathrm{K}\right)
\end{array}\right\}
$$

where, the values of $b_{1}-b_{4}$ are shown in Eq. (31)'.

The values of $\Delta S^{\circ}{ }_{298}$ thus calculated are shown below.

$$
\left.\begin{array}{ccc}
\text { Reference } & \text { Fujishiro } & \text { Leitnaker, } \\
\left.\Delta S^{\circ}{ }_{298} \text { (e. u. }\right) & +1.3 & +8.7 \\
\text { Lonsdale, } & \text { Alcock, } & \text { Eick, } \\
\text { Graves } & \text { Grieveson } & \text { et al. } \\
+8.7 & -0.7 & -1.3
\end{array}\right\}
$$

\begin{tabular}{|c|c|c|c|c|}
\hline $\begin{array}{l}\text { Com- } \\
\text { pound }\end{array}$ & $\begin{array}{l}\Delta H^{\circ}{ }_{298} \\
(\mathrm{kcal} / \\
\text { mole })\end{array}$ & $\begin{array}{l}\Delta G^{\circ}{ }_{298} \Delta S^{\circ}{ }^{209} \\
\text { mole) } \\
\text { moli })\end{array}$ & $\begin{array}{l}S^{\circ}{ }_{298} \\
(\text { e.u. })\end{array}$ & Reference \\
\hline UC & $\begin{array}{l}-20.8 \\
\pm 0.9\end{array}$ & $-20.5-0.9$ & 12.5 & $\begin{array}{l}\text { Huber \& Holley } y^{(1)} \text {, } \\
\text { and Alcock \& } \\
\text { Grieveson }\end{array}$ \\
\hline \multirow[t]{7}{*}{$\mathrm{UC}_{2}$} & $\begin{array}{l}-18.0 \\
\pm 4\end{array}$ & & & Huber \& Holley ${ }^{(1)}$ \\
\hline & -25.3 & $-25.7+1.3$ & 16.1 & Fujishiro(13) $^{(13}$ \\
\hline & -17.7 & $-20.3+8.7$ & 23.5 & $\begin{array}{l}\text { Leitnaker \& } \\
\text { Witteman }^{(14)}\end{array}$ \\
\hline & -15.3 & $-17.8+8.7$ & 23.5 & $\begin{array}{l}\text { Lonsdale } \& \\
\quad \text { Graves }^{(15)}\end{array}$ \\
\hline & -28.0 & $-27.7-0.7$ & 14.1 & $\begin{array}{l}\text { Alcock \& } \\
\text { Grieveson }^{(8)}\end{array}$ \\
\hline & -43.4 & $-43.0-1.3$ & 13.5 & Eick, et al. ${ }^{(\theta 1)}$ \\
\hline & -18.0 & $-19.2+4.2$ & 19.0 & $\begin{array}{c}\text { Huber \& Holley }{ }^{(1)} \text {, } \\
\text { and Alcock \& } \\
\text { Grieveson }{ }^{(8)}\end{array}$ \\
\hline
\end{tabular}

From Eqs.(18),(33) and (34),

$$
\begin{aligned}
& \Delta S^{3}{ }_{T}=-27.35+13.59 \log T-8.02 \\
& \times 10^{-8} T+0.35 \times 10^{5} / T^{2} \\
& \left(298^{\circ} \sim 935^{\circ} \mathrm{K}\right) \\
& \Delta S^{\circ}{ }_{T}=10.94-2.303 \log T\left(935^{\circ} \sim 1,045^{\circ} \mathrm{K}\right) \\
& \Delta S^{{ }}{ }_{T}=-3.65 \quad\left(1,045^{\circ} \sim 1,405^{\circ} \mathrm{K}\right) \\
& \Delta S^{\circ}{ }_{T}=-1.36 \quad \text { (above } 1,405^{\circ} \mathrm{K} \text { ). }
\end{aligned}
$$

Then $\quad \Delta S^{\circ}{ }_{298}=+4.2$ e.u.

These results obtained are summarized in Table 1.

Table 1 Thermochemical functions for the formation of uranium carbides

\section{-REFERENCE- -}

(I) E.J. Huber, Jr., C.E. Holley, Jr.: Symposium on the Thermodynamics of Nuclear Materials held on 21 25 May 1962 in Vienna, Paper No. SM26/26, (1962).

(2) J. J. W ARD: BMI-1313, edited by A.B. Tripler, et al., (1959).

(3) J.J. KaTZ, E. RaBinowitch: "The Chemistry of Uranium", 219, (1951), McGraw-Hill Book Co., Inc., New York.

(4) A. Boettcher, G. Schneider: Second United Nations Intern. Conf. on Peaceful Uses of Atomic Energy, A/Conf. 15/P/964, (1958).

(5) T. MUKaiBo, et al.: Symposium on the Thermodynamics of Nuclear Materials held on 21 25 May 1962 in Vienna,Paper No. SM-26/11, (1962).

(6) J. W. DROEGE, et al.: $B M I-1313$, edited by A.B. Tripler, et al., (1959).

(7) J. D. FARr, et al.: J. Phys. Chem., 63, 1455 (1959).

(8) C. B. Alcock, P. Grieveson: Symposium on the Thermodynamics of Nuclear Materials held on 21 25 May 1962 in Vienna, Paper No. SM26/6, (1962).

(9) L. BREWER, et al.: "The Chemistry and Metallurgy of Miscellaneous Materials, Thermodynamics", edited by L.L. Quill, National Nuclear Energy Series, IV-19B, (1950), McGraw-Hill Book Co., Inc.

(1d) L. BREWER, et al.: MDDC-1543, (1945).

(1) O. KRIKORIAN: UCRL-2888, (1955).

(12) C. B. Alcock, P. GRIEveson: J. Inst. Metals, 90, 304 (1962).

(13) S. FUJISHIRO: This Journal, 3, No. 12, 913 917 (1961).

(14) J. M. LeitnakeR, W. G. Witteman: J. Chem. Phys., 36, 1445 (1962).

(5) H. K. Lonsdale, J. N. Graves: Symposium on the Thermodynamics of Nuclear Materials held on 21 25 May 1962 in Vienna, Paper No. SM26/33, (1962).

(16) H. A. Erck, et al.: ibid., SM-26/39, (1962).

(17) F. D. Rossini, et al.: "Selected Values of Chemical Thermodynamic Properties", National Bureau of Standards Circular 500, (1961).

(18) O. KUBASCHEWSKI, E. Evans: "Metallurgical Thermochemistry", (1958), Pergamon Press, London.

(19) H. NowotNY, et al.: Planseeberichte für Pulvermetallurgie, 5, 102 (1957). 